\title{
A POPULAR CULTURE RESEARCH ON AMERICAN HEGEMONY IN TRANSNATIONAL WOMEN MAGAZINE ADVERTISEMENTS
}

\author{
Ekawati Marhaenny Dukut \\ English Department, Faculty of Language and Arts, \\ Soegijapranata Catholic University, Semarang \\ ekawatimd@gmail.com
}

\begin{abstract}
Women magazine advertisements from the United States of America (U.S.A.) cross border in space of time and location due to the transnational characteristics of American popular culture. By traveling through spaces of time, an advertisement from previous years is possible to come up again in many years after. This occurence happens in some U.S. women magazine advertisements. Meanwhile through spaces of location, U.S. magazine advertisements can also be published in magazines from other nations with almost no real difference in its visualizations, like what happens in Indonesian women magazines. Scholars claim the occurrence is influenced by the American hegemony phenomena. Working under the American Studies discipline, the researcher chooses a total of 3621 women magazine advertisements from the 2007-2008 issues of U.S. Ladies Home Journal, O: The Oprah Magazine, Cosmopolitan; Indonesian Cosmopolitan, Kartini, and Femina, as well as 1960 Ladies Home Journal to become the main data for research. In her research, a thread of popular culture, consumer culture and gender ideology perspectives are found. First, through popular culture, the advertisements gain an easy acces for transnationality and globalization. Second, through consumer culture, the researcher finds that women are acknowledged as the highest potential as consumers because they are the decision makers of their own family's household expenses. Third, by dissecting and analyzing the advertisements in more detail, the research also finds that gender ideology confirms how society still want women to maintain the traditional roles of women as mothers and housewives.
\end{abstract}

Keywords: Transnational American Studies, popular culture, hegemony, gender ideology

\section{INTRODUCTION}

Crisscrossing influences in global society today is an absolute phenomenon because in the era of globalization where cultures are becoming transnational, people have difficulty in distinguishing what becomes the characteristic of a nation due to the emergence of borderless areas among nations. With regards to the phenomenon, it is interesting to take note of Kraidy's opinion (2002) that with globalization, the culture of "the entire world has been molded in the image of a Western, mainly American, culture" (p. 1). Part of the reason for this particular condition is because in foreign and domestic policies, according to Beeson (2004), America has assumed "an unprecedented prominence in the affairs of other nations and regions as they seek to accommodate, and where possible benefit from, the evolution of American hegemony" (p. 1). The hegemonic status of being the most powerful country on the planet has been continually maintained by America with their popularity of American products, such as the mushrooming of McDonald's restaurants and the worldwide spread of the credit card (Ritzer, 1998). The credit card has especially encouraged people to continually buy American products with ease, thus, support the continual hegemonic status America has over other nations. In Crockatt's view (2007), however, American hegemony is not only caused by the global service of credit cards, but it is also caused by the identification of the U.S. as a country which is incomparable to 
others due to the understanding that America has been regarded as the chosen country to lead and become the savior of all nations ( $p$. 16). In relation to this, Ferguson (2003) observes that America's massive economy output, powerful military and soft cultural power has also led America to hegemony and therefore makes an undeniable picture of the reality of American globalization (2003, p. 21).

America's globalization is said to have taken into account of Marshall McLuhan's prophecy (2002) of the "Global Village" (p. 1). In this village, McLuhan predicts that by way of electricity, unique cultures of certain countries are blending into one another to produce a global village of similar cultures. After half a century later, the electricity media McLuhan talks about is revealed in the occurrence of the internet. The internet, which reaches great distances through its increasing speed (Vertovec, 1999, p. 1) has created an invisibility of areas' boundaries. With much information on the many kinds of American products that are available within a single click, the American popular culture has easily crossed the borders of many nations. For this reason, Ritzer (1998) argues that America's culture is tied to no place and no period when he cites Smith who believes that the characterization of globalization is "contextless" because it is "a true mélange if disparate components drawn from everywhere and nowhere, borne upon the modern chariots of global telecommunications systems" (p. 84).

In this discussion on the cross bordering phenomenon of context-less communication, America is witty in not only taking advantage of the digital media of the internet but also through a more conventional print media, such as the magazine, which is prepared for cultures whose modern digital technology is still limited. Through either digital or printed media, therefore, a person from anywhere in the world can learn and be immersed in the American culture. Through the digital and print media, global citizens are potentially influenced to dress up, behave and think like the Americans.

As an example, the popularization of the McDonald's burger not only increase America's economy and elevate its hegemonic status, but it has also introduced the modern fast food eating habit for people on the run. The American eating habit and its effect on transforming other nations' way of thinking is, consequently, making it increasingly difficult to recognize the origin of someone's culture. The uncertainty of someone's origin is based on W.B. Yeats' belief on globalization as the factor for the "Western world [that] is going Eastern, even as the East goes Western" (McLuhan, 1964, p. 44). The intertwining of the Asian and American culture above is, in other words, caused by the global or transnational character of American popular culture.

A study on American popular culture, which deals with the everyday life phenomenon of what Americans do during their spare time and what they listen to, talk about or wear each day is an interesting, likewise, important area of American Studies research. This is especially relevant when considering that the Indonesian culture, according to Beng-Huat (2000) is heavily influenced by the existence of American popular culture. With American popular culture easily transnationalized across the globe, Beng-Huat reports that most Indonesians aspire to be Americans. Not only do Indonesians admire whatever is American, but they see the need to buy American products, which are advertised in women magazine advertisements, in order to be identified as a member of the world's leading global citizen. In Beng-Huat's understanding (2000), Indonesians feel a sense of pride in using American products because it not only 
"signal self-identities" but also establish and "maintain membership of collective identities" (p. 137). In support of this, Warde (1994) comments that,

today, people define themselves through the messages they transmit to others through the goods and practices that they possess and display. They manipulate or manage appearances and thereby create and sustain a "self-identity". In a world where there is an increasing number of commodities available to act as props in this process, identity becomes more than a matter of the personal selection of selfimage. (p. 878)

In other words, to an Indonesian the purchase and use of American commodities is a crucial need in showing their identity. The American popular culture product helps transform Indonesians' appearances and identifies them as members of a leading global group. The products or American commodities, thus, have a hegemonic nature. In relation to American Studies research, therefore, a number of questions arise. First, is how the magazine advertisements as a media of promoting the American products can influence women magazine readers to be interested in and trap them into a consumer culture. Second, is how they scan ignal the dream of achieving a global self-identity. Third, because most of the advertisements are published in women magazines, it is also interesting to question whether the women images used in the advertisements have a gender ideology influence behind them or not.

\section{THEORETICAL FRAMEWORK}

The above phenomenon on the crossbordering of culture and American hegemony is also experienced in the field of American Studies when facing the development of the U.S. In the New American Studies, Rowe explains, "Where traditional American studies focus on one single dominant culture that assimilates with other immigrant cultures, the more recent or New American Studies focus on the cultural hybridities that have occurred historically among the many cultures that constitute the American nation." (Rowe, 2002, p.12). In her argument, Rowe (2002) also expresses that American Studies scholars are strongly encouraged to give attention to the "intersections and interactions" of the different cultures in America, which help make up the "cultural hybridities" that constitute its people (p. 167). The focus on cultural hybridities in the New American Studies approach, have encouraged scholars to make use of the coming of the multi-cultured immigrants in America as an important history to the shaping up of the country. It is this cultural hybridity in women magazine advertisements that may be the key to the strong hegemony position of American popular culture.

In the field of American Studies, the crossbordering phenomenon is equivalent to the transnational phenomenon of popular culture. As informed above, in the transnational culture of American hegemony, a cultural hybridity arises from America's multicultures. Rowe's view, which sees the effect of the immigrant's culture variations in American history as an important element of research in American Studies, is the same with Fishkin, another distinguished American Studies scholar's view point. It is Fishkin, who has been encouraging American Studies scholars to acknowledge scholarly research by embracing the complexities behind the building up of an American identity (2004, p. 1). Although initial discussions of the concept have begun since the 1990s, it was not until 2004 that Transnational American Studies as a theory is formalized by Fishkin (2004) in her American Studies Association's presidential address. In order to understand the whole American culture, she states: "The goal of American studies scholarship is not exporting and championing an arrogant, pro-American 
nationalism but understanding the multiple meaning of America and American culture in all their complexity" (p. 20). This means that Fishkin believes American culture is a result of not just one single culture but a result of a hybrid of cultures that spring up from the various immigrants that make up America. Fishkin (2004) also exclaims that "Today American studies scholars increasingly recognize that that understanding requires looking beyond the nation's borders, and understanding how the nation is seen from vantage points beyond its borders" (p. 20). Her address, opens up the understanding that in looking at America, the place of American hegemony's self-regard would permit scholars to gain more distinction and better multicultural understandings of what was or could be defined as American. This hints that with transnationalism in New American Studies, theories of cosmopolitanism and post-national conception of global or planetary citizenship is now intellectually challenged.

As understood from the above discussions, in dealing with a global phenomenon, research that deals with what most people "listen, buy, read, consume, and seem to enjoy to the full" (Hall, 2002, p. 446) and "do in their dominant culture" (Hall, 2002, p. 448) is important to do. The advent of American popular culture that is made transnational through women magazine advertisements is a factor that causes the country's position to have a strong relationship with other countries. The popular use of Google facilities with that of Apple computers and Ipads are proof of how American popular culture has been an influencing leader to the world. Like informed by Beng-Huat's (2000) and Warde's (1994) above in his "self-identity" proclamation, owning an American popular culture product is understood by Indonesians and other nations as a realization for a "sense of freedom, personal power, and status aspiration" (Tomlinson, 1990, p. 6). These are tempting people to be consumptive in their lives. To these people, the more American products they have, the more hegemon they can be. Yet in consuming American popular culture products, Indonesians and other countries often do not realize how powerful the American culture is in changing the people's lifestyle and every day habits.

The hegemonic influence America has over other nations, such as Indonesia via its popular culture products has made some strong impact to the local culture. When Indonesians interact with American popular culture, they are unconsciously sending and absorbing the new culture with others' cultures, too. In the process, there is a tendency for a shift or reconstruction of the cultural belief when absorption of globalized American products is being concerned. Thus, not only do Easterners become influenced by the Western culture, but at the other end, the Westerners are also getting impressions from the Eastern countries. This article, therefore, makes a discussion on an American Studies research which deals with American hegemony by way of popular women magazine advertisements.

\section{METHODOLOGY}

The data source for the research reported here is advertisements from three popular U.S. women magazines of 2007-2008, i.e. Cosmopolitan (905 advertisements), Ladies' Home Journal (587 advertisements), and $O$ : the Oprah Magazine (786 advertisemnts); and three popular Indonesian women magazines, i.e. Cosmopolitan (723 advertisements), Kartini (102 advertisements) and Femina (170 advertsements). This particular year frame is chosen because there was a world economy recession or crisis in 2008, thus gives the assumption that there are more advertisements of products in the magazines. Yet, by comparing it to the year before, i.e. 2007, the 
research finds that the number of advertisements published in the six magazines do not have any significant difference in number. Thus, the economic recession experienced by people do not directly affect how many industries choose to pay up for promotions through magazine advertisements.

The research on magazine advertisements uses Cosmopolitan because it is acknowledged as the most popular franchised magazine, which is brought transnational across the world. In almost any country, there is Cosmopolitan magazine. This gives reason why Cosmopolitan Indonesia is directly compared to the U.S. version. The transnational phenomenon of the magazine advertisements in the sample of the U.S. Cosmopolitan magazine, according to Lagani in a YouTube interview has the position as the "number one magazine in the world" (2009), thus, it promises a better understanding on the study of women magazines as a representation of how the factor of space or location can result differences in the choice of American popular culture products advertised in American women magazine versus the Indonesian ones.

The transnational characteristics on popular culture also forces the research to deal with the borderless boundary of space time. As a representative for this, there is a seventh magazine, i.e. the selection of 1960-1961 Ladies' Home Journal magazine (348 advertisements), which is reknowned as the pioneering and most long standing magazine in America. In seeing the similarities and differences of the 2000s edition versus the 1960 s, the research can find whether or not there has been a development in women's image that is used as the models for the American popular culture products advertised in the magazines. This step is important to do, since a Philadelphia advertising agency, N.W. Ayer and Son, has opened up the understanding that advertisements have a high credibility in an historical reconstruction (Marchand, 1986, p. xv). The fact that America is formed from multi cultures, also makes it necessary for the research to use magazine advertisements from $O$ : the Oprah Magazine that is founded by an AfricanAmerican in the year 2000 .

Femina and Kartini are two of the most popular women magazines circulated in Indonesia. These magazines are used as the variable to see how transnational are the American popular culture's products advertised in magazines. The more transnational the advertisements are, then some advertisement from either the American Cosmopolitan, Ladies' Home Journal, and $O$ : the Oprah Magazine could be found in the Indonesian one without any changes in eother the visualization and verbal texts. Yet. Since transnational also entails cultural hybridity, the research also wants to see what has the Indonesian copywriters do to accomodate the Indonesian audience for the American products advertised in the Indonesian magazines.

\section{DISCUSSION \\ SUCCESS OF CROSS BORDERING NATIONS WITH WOMEN MAGAZINE ADVERTISEMENTS' FREEDOM IMAGERY}

America is stereotyped as a country, which offers its inhabitants to have the freedom in choosing the kind life one wants to have without any real hindrance from anyone. In analyzing the kinds of imageries advertisements offer to women, the most frequent imagery found in the research is one that represents the value of freedom. The expression of freedom, in this case is supported by imageries that show a democracy of working independently or being self-reliant and in the self confidence of making decisions in purchasing the approriate 
products advertised in the magazines for the benefit of the family.

In the U.S., the exercises of democracy for its people commences by giving low affordable prices to magazines. If, for example, a college or foreign graduate student can have a stipend of U.S. $\$ 1000$ and the price of a newly published magazine is around a U.S. $\$ 3$ to $\$ 5$ range that means it is less than $1 \%$ of the stipend, thereby it makes possible for everyone to buy and read a magazine. In reading a magazine advertisement, there is no boundary of race, age or gender, so the price range should accommodate for as many people to consume it. Next, magazines are the media for women's aspirations to work independently and pursue for a career. Thus, in magazines there are various kinds of modern technology advertisements that decrease the burden of women's housework and office work duties, so that in doing the duties women are encouraged to do them alone without asking for any assistance from the men. Magazines also teaches women to speak up freely and express themselves through forums of making complaints, suggestions or answering questions for polling purposes, thus advertisements that show images on making women feel more worthy as a human being are often used deliberately to attract potential consumers. For this reason, magazine advertisements often offer chances for women to exercise their own decision making in purchasing advertised products to achieve a more comfortable life in either the U.S. or Indonesian setting.

Some prominent issues which are related with the freedom imagery of women are shown, first with the idea that women can do so much more and better with the conditions they already have. The issue of women's selfactualization is presented in, for example, the hair spray magazine advertisement which holds the women's hair even though she moves about a lot. From an advertisement in
USA Cosmopolitan, February 2007, p. 84, it is seen that a woman freely laughs out loud at the accomplishment she has done with her hair spray. The image seems to point to how in every way she moves, her hair manages to hold well into place that she is satisfied with the result of her hair spray. Spraying the hair spray around herself is an expression that signifies the feeling of a personal achievement in using the product. The way she dresses herself with a sleeveless top that show off some of her beautiful body curves is also a sign that she has a high self-reliance of the independence of whatever she can do to elevate a self-confident feeling. The text at the bottom right that says "BEAUTY THAT HOLDS" not only signifies how the hair spray holds her beautiful hair in place, but also in how she holds her audience's breath for the beauty she is expressing.

In Indonesia, the freedom of being a selfreliant person is manifested in the ownership of a credit card. The offering of the "Lady Series" card from Lippo Bank promises the possibility of women achieving and possessing many things. She could choose the Lady Pink card to get her to Paris, or the Lady Diamond card to buy the shoes and gown she needs to see a theatrical performance, or the Lady Gold card to get her shopping and bring back packages of goodies. Women can freely go anywhere, do anything and buy whatever she wants with a bonus of $5 \%$ savings. In the Lippo Bank Lady Card (Femina, 29 Mei-4Jun 2008, p. 109) there is the promise of a bonus or discount, which becomes a marketing strategy that most Indonesian consumers often look forward to. In other words, credit cards to Indonesians are identical to discounts on something rather than as a way to make a down payment on an important asset.

In the same magazine, Femina, the offer of a credit card from BII and BCA all have discounts to the other leisure activity 
Indonesians love to do, i.e. eating Western food at U.S. franchise restaurants. For BII, it is offering the purchase of satay kebab with as much as $50 \%$ discount to merchants and restaurants listed in the advertisements, whereas for BCA it is offering a $15 \%$ off to the pizza menu available at a Pizza Hut restaurant. Somehow eating a Western food and paying it with a credit card for the Indonesian consumer signifies a higher social status. The advertisement on a Citibank credit card, however, chooses to use fashion jewelry accessories in the picture. This means that the value of the American credit card is not delegated like for the Indonesian middle class who loves to use it for food, but instead the American credit card is for the high class, thus, the image used in the Citibank card is diamond ring and bracelet, and a matching glittery purse. Instead of a discount for the purchase of the jewelry, Citibank is offering a $0 \%$ installment. Interestingly, advertisements on credit cards are not seen in any of the U.S. magazines chosen as data. The credit card is already a culture for the Americans that the advertisers assumes everyone already has one and so there is no need to advertise. If in Indonesia people still need to be influenced into making a credit card, for Americans it is odd to see someone only having a debit and no credit card.

America is known as a consumer country. This implies that it is ordinary to have people pay in credit for the things they need. In lifestyle, this effected the way Americans could easily donate their materials for others even though the thing they are donating is still in god quality or have only been used for a couple of months. By comparison, for Indonesians parting with their material is hard to do since buying it was by debit card or by cash, thus, there is a tendency for passing down materials to others only when the material is already bad in quality or no longer meet the kind of prestige Indonesians seek by having the material. Indonesians see that the experience they had in the past with their materials is something to treasure and retold to their grandchildren. By comparison, Kluckhohn and Strodbeck (1961) point out that the U.S. is a very future-oriented society. Freedom imagery is supported by how optimistic and self-confident the models in the advertisements are. For example, a backless dress worn by a model signifies the daring attitude a woman can do in proudly exposing her back and thus become the center of attraction by the male counterpart. The expression of the model which shows a daring and full of confident attitude signifies the selfactualization and awareness of her own sexy body and its power to 'allure' men, that all men, as represented in the advertisement's background see her as the ideal type of woman. This image is seen in the Giorgio Armani perfume advertisement in the Indonesian Cosmopolitan, February, 2007, p. 21. It is, however, interesting to point out that the magazine uses the hybridity of a halfnaked female Caucasian model with the backless dress. It is as though a confirmation that only Western foreigners are allowed to act the way they are. However, the appearance of the female model with brown hair and dark cosmetics or make-up in the advertisement makes her looking similar with an Indonesian woman which brings a sense of closeness to signify that Indonesian women are capable to achieve the same thing.

A year later, a similar attempt in showing how a woman are free to express oneself by being daring with her half-naked body is found in a Vaseline product advertisement. In it is used an Indo-European model, Dewi Sandra, whose hair is colored brunette, thus from afar she looks Western (Indonesian Cosmopolitan, November 2008, p. 153). Although Dewi Sandra is an Indonesian actress, the background of one of her parent being a Westerner allows her to show off her sexy 
back like in the Giorgio Armani perfume advertisement.

Looking through the number of advertisements in the Indonesian Cosmopolitan of 2007-2008, no advertisement with a backless and fully bred Indonesian model is found. This shows that although the magazine is franchised, it realizes its Indonesian audience and thus carry on the culture that it is impolite to fully show one's sexy self in public.

Yet, in finding out whether there are instances of exactly the same advetisement from the U.S. Cosmopolitan and Indonesian version, women's freedom imagery is found in the Calvin Klein product's advertisement on jeans, which shows off the film star, Brooke Sheilds and Kate Moss. The Brooke Shields advertisement in the 1980s shot by Richard Avedon, was a popular advetisement because of the first of many taboo-breaking Klein advertisements. It showed the fifteen-year-old Shields, who is innocent with long straight hair and clear eyes, wearing a Calvin Klein is turning slowly towards the camera is asking boldly, "Know what comes between me and my Calvins? Nothing". People may vaguely know Brooke Shields before they saw the advertisement. The word "Nothing" in the advertisement also points to her experience of starring in the Blue Lagoon as a teenager, who shows her nudity. It is this nudity scene that makes her chosen as the icon for Calvin Klein's sex appeal.

A decade later, Brooke Shields is replaced by the supermodel, Kate Moss whose thin body became the next celebrity for the Calvin Klein jeans and perfume. During that time, America sees the twiggy style as popular, thus explains why Kate Moss is chosen as the mode. When Klein saw that Americans were ready for more and more suggestive or sexual advertising, he made sure that he and his clothing were in full view of a series of provocative advertisements. Calvin Klein's perfume advertisement, which is published in both the 2007 U.S. Cosmopolitan and Indonesian Cosmopolitan, however, do not show off half-naked bodies, but instead show a fully clothed Kate Moss with sexually provocative gesture with a guy as though they were about to make some kind of sexual favors.

The freedom expression of women, such as mediated by Kate Moss in her provocative gesture is an example how women freedom imagery in advertisements is usually used to help spread consumerism in both American and Indonesian magazines. In fact, many advertisements often use women models that challenge their readers either in their gesture, the clothing they wear or in the language style or vocabulary used to help advertise the products through the magazine as media for promotion. This use of women magazine as a media for advertisements has been done ever since the post-World War II era. Since that time, women's magazine in cooperation with industries used demographics to research and classify their readers in order to make predictions about their consumption patterns (Gough-Yates, 2003, p. 2) and find ways to ensure that the advertisement in the magazine is continually popular and enhance the promotion of the industries' products. This condition has constructed a "women's market" ever since the 1950s (Winship, 1987, p. 46). In the attempt to seduce women to buy more of the products, this research analysis of advertisements finds that women's freedom imagery is mostly used as a strategy to globally market the industries' products.

By the late 1970s, research on the motivation of women consumers was replaced by "lifestyle segmentations" (Gough-Yates, 2003, p. 2), which shape the new image of women who are decision makers of buying the products. In the 1990s, however women's 
magazines shifted their representation of women to having sexual confidence and independence, when researchers found the new middle class consumers call for "pleasure as a duty, self-expression, bodily expression and natural sexuality" (Gough-Yates, 2003, pp. 140-143). It is for this reason that in both American and Indonesian Cosmopolitan magazines, many of the advertisements rely on sexual scenes to elevate a freedom imagery for women via advertisements.

In showing how women can exercise her freedom of choice, advertisements also offer that there is strength in women collectivism, which is represented in the notion of sisterhood. Women has been noted to usually gather in a group along with other women. Groupings with fellow women strengthen ones sense of belonging. According to Lindquist and Sirgy (2006) the sense of belonging relates to the terms of security, camaraderie and friendship which strengthen one's position in the society. In collectivism, women are able to actualize themselves by sharing and talking about their daily life problems with their fellow women when they gather with their friends (p. 176). Further, American culture increasingly supports the need to work collectively to solve problems. Despite the fact that the spirit of individualism is still strong for the U.S. people, today's consumers tend to place greater value on teamwork. The advertisement on Nivea body product, which shows three American women of multi race, i.e. an African-American with a Mexican-American and Europen-American are making friendly conversation while applying Nivea body lotion on their legs from O: The Oprah Magazine of May 2007, p. 6869 show the strength of collectivism in women. Through a visual study, the advertisement seem to inform that women can achieve freedom by making use of the opportunity to be together to talk out whatever problems women have. In the advertisement, the problem may be any career and household problems or the dryness on their skin, thus becomes reason why Nivea body lotion is continually needed. (Lindquist and Sirgy, 2006)

In Indonesia, finding strength through collectivism to express freedom is also found in the emphasis of togetherness or gotong royong culture The Indonesian women's tradition of arisan where women are gathered to discuss their problems, eat together, gossip and conduct a kind of lottery, that still persists until nowadays, becomes the media for self expression in the Indonesian Cosmopolitan November 2008, p. 73 issue. The happy smiles of the models signify the happiness of being with friends and enjoy that sense of belonging to a group of woman. Although the product advertised is a handy camera, the message transferred from this advertisement clearly reads: you will be happy when you gather with your friends and you can keep the happiness by capturing it with a handy cam. Interestingly, the advertisement which represents the collectivism value in Indonesian Cosmopolitan magazines is found to only cover $1 \%$ of all the issues within American Cosmopolitan advertisements on collectivism, i.e. around $3.4 \%$ of the advertisement's total data for the research. It is interesting to note that in Indonesian magazines, collectivism is usually shown in relation with the product of technology.

\section{PATRIARCHY HEGEMONY IN WOMEN'S LIFE AS A PARADOX TO WOMEN'S FREEDOM}

Advertisements in magazines are paradoxical. Although advertisements can be the media to transfer a freedom imagery, they also transfer the confirmation that women are bind under a patriarchy hegemony of keeping women in their own household. For example, in a milk advertisement from a U.S. magazine, the message transfered to its readers is that being 
healthy means that women have the freedom to focus on how to increase their health by consuming as much milk each day as it contains a high dosage of vitamin D. As shown in another U.S. milk advertisement, an elderly woman is seen to have a 'white' mustache to prove that she has just drunk milk. This scene opens the idea that there is no restriction as to whom can consume milk for health. No matter how young or old, how busy you are as a manager of an office or business woman or a mother of a baby is, or how sexy a red dressed actress is, in a series of Got Milk advertisement the accompanying text "In show business your figure shows. That's why I drink milk" (Ladies' Home Journal August 2007, p.3) and "Staying active, eating right, and drinking 24 ounces of low fat free milk a day helps you look at your best" (O: The Oprah Magazine, February 2007, p. 41) Got Milk advertisement has become proof that women are free individuals, who can choose to drink milk as a daily beverage to keep healthy.

By comparison, although Indonesian advertisements on milk produce are also valued, women models used give out the image that it is the duty for mothers to buy milk for her family. Therefore, it does not elevate the sense of freedom imagery that the American Got Milk advertisement above has. The Indonesian mother positioned around a dining table and kitchen has instead solidify the meaning of patriarchy hegemony. The explanation for this is, it has not become a habit yet for Indonesians to drink milk every day. Thus, milk in the Frisian Flag advertisement from (Femina 24-30 May 2007, p.135 is still exclusively limited for the growing children and not for every member of the family.

Reflecting back to the Ladies' Home Journal magazine advertisements in the $1960 \mathrm{~s}$, it is interesting to find that like the Indonesian magazine advertisements, the women are given patriarchy hegemony images. As proof almost all of the images of women in the 1960s advertisements, women models have been located in kitchens doing household chores. Examples are women, who are promoting laundry detergents, or dishwashing detergents, which claim that the ingredients in the detergents can still leave women's hands silky smooth. If women are shown some kind of freedom, it is usually found in fashion and cosmetics advertisements, where men are often pictured as lurking beside the women while giving compliments on how beautiful are the women. Scenes like these do not really impress women as having freedom, but instead have strengthen the men as the agent who makes women feel beautiful. In other words, women need men to defone them as beautiful creatures.

\section{THE GENDER IDEOLOGY OF WOMEN IN MAGAZINE ADVERTISEMENTS}

In Friedan's The Feminine Mystique (1974), out of a sample of 4,500 wives that are from middle-class, high school or college educated American women were divided into three gender ideology categories, they are either the True Housewife, The Career Woman, or The Balanced Homemaker type (pp. 199-200).

In the first category, housekeeping becomes the main interest of these women that the comfortable and well-running home for her family is something that makes her proud and satisfied that she would not want to exchange it with any other type of job nor will anyone be able to take over the job she is managing. It is in this Housewife type of women that appliance marketers see the potential of selling their products to, thus becomes the main reason why 1960s advertisements are filled with household appliances. In the research, it is found that $7 \%$ of a total of 3621 advertisements under scrutiny follow this rule. 
The second category is the Career Woman. In here, Friedan expresses her belief that women are the minority and extremely unhealthy according to the product sellers' point of view because although women would buy appliances, such women do not believe their primary place is in the home and thus are considered too critical by sellers.

Meanwhile, in the third category, the Balanced Homemaker, is regarded as the ideal type by Friedan. In the research, a number of 1960s magazine advertisements do show that women having some outside interests or holding a job before turning into the career of homemaking, would make women readily accept any kind of help a home appliance mechanic offers. Although accepting the male mechanic's help, women do not surrender fully to him because she can still exercise her managing qualities to make the man do whatever is necessary to well-run her household.

Through a consumer perspective, the research finds that the development of women's equality of rights to a workplace outside of the home have resulted marketers, who devised ways for appealing these women with an $\mathrm{X}$ mix aid so women are influenced to spend the family's money to get rid of the boredom in the home by creatively doing something. Friedan exclaims:

Every effort must be made to sell X Mix, as a base upon which the woman's creative effort is used.

The appeal should emphasize the fact that $\mathrm{X}$ Mix aids the woman in expressing her creativity because it takes the drudgery away. At the same time stress should be laid upon the cooking manipulations, the fun that goes with them, permitting you to feel that X Mix baking is real baking. (1974, p. 202)

In her book Shaping Our Mother's World: American Women' Magazines, Walker (2000) also discussed the role of magazines as a business of expressing editorial philosophies to readers who yearn for personal, social and family advice, in addition to providing entertainment and information about the period of 1940 to 1960 that celebrated women's primary role as a cook and creative homemaker (pp. viii-ix). Especially for the 1950s, Kammen (1999), in his American Culture, American Tastes: Social Change and the 20th Century, also added his argument that the American family was immersed in the claim that the rise of income in the economic sector has developed a culture of what used to be a 'need' to become into a 'want' of something for the newly targeted women consumers.

There has been a saying that one should keep up with the Joneses to mean whatever the Jones's family has, it has got to be whatever one has also. During the 1940 to 1960 s period of popular culture affluence, although not needing a dish washer machine, since washing dishes for a small family of four is still manageable to a housewife; the saying has influenced women to have what their neighbors have to keep up with the current trend of their society. In connection to this, advertisers are clever to put in a philosophy in their advertisements that is not wrong to want one of their products, too, for the sake of modernity or as a show-off to party goers. This American attitude of wanting to have whatever their neighbors' have has made some dilemma when at the war time, mass produced things became scarce due to the limitations of manpower at factories.

With men going to war as soldiers, women had the chance to join the work force and did a man's job. Joining the work force for women was not a matter of choice, however. Women had to work because some could not live with the small "pittance" given by the government as dependents of their husbands 
(Walker, 2000, p. 84). However, this condition created a controversy about the morality of motherly and domestic work with that of public employment (Walker, 2000, p. 67).

Walker explains that during the war, women's magazines target their readers to become nationalistic by supporting the war as army helpers who would "roll bandages, knit warm clothing for servicemen, distribute ration coupons and work for the Red Cross" (2000, p. 80). However, by contrast, after the war, the 350,000 'Rossie the Riveter' women who joined the Women's Army Corps were asked to return to their cultural role as the controller of their domestic world and engage in their lifelong, unpaid employment. A magazine article entitled "Women Work for Their Country" written by Dorothy Dunbar Bromley was in support of this cause, when she wrote in Women's Home Companion (December 1941) that in being a woman,

You needn't pilot an airplane, nurse in the army or go into a munitions factory to be of help. There are a number of important though less dramatic things to be done. Volunteer as an air raid warden, drive soldiers and their families to and from camps, entertain at the service clubs and at home. At Traveler's Aid booths in a hundred cities trained volunteers hand out information to boys on week-end leave.

Take a home-nursing course or be a gray lady - a hospital assistant. Study nutrition at a Red Cross class and keep your family well, or study canteen work for larger-scale feeding. If you are qualified teach instead of learn. And when spring comes plant a vegetable garden. (Walker, 1998, p. 35)

To be a woman, therefore, necessitates a far more important duty in the household where a women, can be her own boss rather than becoming a laborer in a work force. According to the article "The Married Woman Goes Back to Work", which was published in Woman's Home Companion of October 1956, women went to work for three reasons:
First of all, there's the obvious answer money. But statistics show few women need the money for survival...

The second thing that drives women out of the house and into an office or factory to earn a weekly check is prestige...

"At last," a woman, who operates a punch machine in a printing plant, said, "I have something to talk to my husband about in the evening..." (Walker, 1998, pp. 88-91)

The three reasons mentioned connotes that whatever a woman makes outside of the house is regarded an event to have extra money. As implied by the article, the required necessities of the home seem to be sufficiently supplied by whatever earnings any man of the house would earn. Because of that, a woman working, means that she has a higher status in society because she belongs to those who are not in the normal position of a full-time housewife.

The prestige women feel when working outside the home is made possible because the women can get acquaintances with outside people who would deal with their husbands. This makes women feel they are as equally knowledgable as their husbands. Yet in that situation, a woman is also challenged with the following a number of questions from Walker about work (1998, pp. 91-96). First, in the question "Can you afford to work" a woman is made to realize that by working the family will have to have an additional expenses due to the kinds of wardrobe, beauty care, transportation costs, telephone calls and lunch hour activities such as window shopping. A woman worker is challenged to the idea that if she earns only 75 cents an hour, she may not break even when paying a child care assistant for the same 75 cents because the woman will still have to find extra money somewhere to pay up for her federal income tax, which comes up to 23 cents. The article puts up the following remark:

To be absolutely realistic, then you should add up all of the hidden costs that may be 
entailed in your working, then figure out how much you will have to earn in order to pay these costs plus your income tax. If your expenses will be $\$ 50$ a week, and your husband's income will put your whole paycheck into the 30 percent bracket, you'll need a salary of $\$ 71.50$ to break even. (Walker, 1998, p. 93)

The arithmetic bluntly tells women that it really is not worth working outside the home because a woman cannot afford to have one, so the only best solution is for women to just conform to society's rule of becoming obedient housewives.

Second, in the question "What can you do", the magazine article mentions that the home and community experience have given a woman a certain balance, maturity, organizational ability and warmth (Walker, 1998, pp. 93-94). However, these qualities are something that employers would most likely not buy as they only go under the heading "experiences" and not professional qualifications. A woman's age is also a factor that would most likely decide employers not to accept a woman on a job. If ever a woman does get a job, it would be teaching elementary school students that gives a salary to around $\$ 84,000$ a year. Talking about profession, a nursing field or hospital administration, requires the applicant to be under fifty and have had two years of high school education. Thus, a woman must have a Bachelor of Science degree, something that even the male counterparts only have some success in meeting the requirements. By contrast, doing office work such as filing, stenography, electric machine punching, book keeping and handling the switchboard is something that large numbers of women are absorbed into doing. Thus, in "what can you do" question, women in the 1950-60s who have not obtained a qualified education and only depended on the housework experience, are made to realize that then there is only a small chance of working outside the home.

Third, in the question "What does your husband think of you working?" there is an inclination that husbands mind about wives and mothers working because the child is the one that often suffers from common colds and the garden that was usually made neat would need pruning once in a while.

Fourth, "Are you healthy and energetic" is a question that makes a woman reflect on the idea that if she decides to accept a paying job outside the home, she must take care of herself well enough in order to return home and still have the energy and health to continue with the daily duties of cooking, wash dishes, sort laundry and be ready as a host in entertaining her husband's friends.

Fifth, "Are you adaptable" is another challenging question that asks whether or not women who are already used to the independence they had at home without any supervision and can be the boss to any kind of home event would enable them to become novices and forget the age to office supervisors who need young, smart, nonsensitive, dependable, and quick working employees. Basically, all five questions want women to get the general understanding that a woman's best place is in the home.

After the war, therefore, it is not surprising to learn that a combination of government and business policies and public opinion has favored the patriarchy system of men by making men return to their industrial jobs, and thus, solidly domesticating the women as homemakers. Although some women are reliable workers, who are helped by magazines with practical advice on how to deal with war or career challenges; the lack of adequate day care facilities, which proceeds to the closing off the centers for their baby boom 
children, has made it difficult for women to look for long-term job opportunities. Rothman (1978) reports that the federal government has only established day-care centers in 1943, where by 1945 only $10 \%$ of them were available for use with very limited facilities and located at inconvenient places, as it was too close to emergency places and encouraged too many women to stay even more at work that rearing their own children no longer became their main duties (p. 223). This consequently, gives reason for some pages of magazines to insert articles that warn women about the increase of juvenile delinquency as a cause for women who decides to abandon their children (Walker, 2000). In the background of this day care issue, Tuttle (1993) comments that there is actually an issue of a male dominated group who regard the entry of millions of women into the paid labor force that was threatening the patriarchal goal of returning women to the life-time performance of unpaid, largely domestic tasks (p. 70).

The above discussions point to the understanding that through magazines women are shown how to become beautiful and attractive with the many kinds of sophistication in cosmetics and how to be practical in cooking; doing housework and using smart clothes for their career. Yet at the same time, through magazine advertisements, women are conditioned to realize as beings that cannot work well unless working in their own household. Magazine advertisements are telling women were to both buy and make savings in the family budget, in order to strive for improved class, and thus should have amiable budget to buy the modern facilitating machines advertised in magazines. For example, the advertisement on the modern gas stove, cooking utensils, sewing machine and vacuum cleaner are claimed to help ease and make quicker the work of the dutiful housewives.
Like the advertisements found in the Ladies' Home Journal, December 1960 issue; in Femina 2007, there is a picture of both mother and daughter showing how happy they are with their LG washing machine that claims to not crease clothes when washed. In it is written: "Cuci pakaian Anda dengan mesin cuci LG! Teknologi perputaran ganda Turbo Drum-nya, mencegah cucian tidak kusut karena terlilit dengan pakaian lain". Likewise, in a 2008 Indonesian Cosmopolitan is an LG refrigerator advertisement that promises consumers to be as classy as the machine and the woman model in red when a consumer decides to purchase the refrigerator. Talking about how the refrigerator is made equivalent with the classy woman is interestingly an idea that is similar to Walker's opinion (2000) about women's magazine advertisements that makes a match of "shiny [white] postwar kitchens" with the "whiteness of the proud owners" (p. 133).

In some respect, this is similar to Tomagola's research finding (1998) that Indonesian women cannot avoid the kitchen even though she has a high education and salary because advertisers have cleverly ensure women that housework does not enslave women because it is an entertainment to make a husband satisfied (p. 341). Unlike the American society, although already in the year 2000s having washing machines and refrigerators for Indonesians are still relegated for certain middle to high class consumers and not for every social class. The kind of visualization and text used in the Indonesian advertisement is found to be one way of enticing women consumers to buy products with the promise of receiving something luxurious in return. By comparison, in the U.S. magazine data used for this research, no advertisements on washing machine and refrigerator are found. This may be due to the understanding that in almost any American house or apartments, these kinds of machinery are already available 
that there is no need for advertising them. The non-availability of washing machines and refrigerator advertisements in the USA magazine is probably a form of negotiation since washing machines are easily accessible in USA neighborhood laundry mats by just putting in some coins into the slots (see LG refrigerator advertisement in the Indonesian Cosmopolitan, November 2008, p. 201).

It is interesting to analyze a vacuum cleaner advertisement, which is claimed to be a must have for any woman. In the November 2007 of O: the Oprah Magazine (p. 142), a Halo vacuum cleaner seems to promise as "the world's only germ killing vacuum cleaner". Meanwhile, a Dyson slim vacuum cleaner which is light weight promises to be "no longer an oxymoron" in the May 2007 (p. 173 ) issue. The word "oxymoron" in the Dyson vacuum cleaner advertisement suggests that in the past the machine were not intelligent enough to pick up dirt, so that through time, the machine continually receives a modern outlook and function. It is also interesting to notice that these vacuum cleaners are not advertised in the USA Cosmopolitan or Ladies' Home Journal which also becomes the main data for this research. One explanation may be caused by the understanding that housework is perhaps racially relegated to the minority groups, such as the African-American mammies, who in the past are referred to household slaves. In the present time, these vacuum cleaners are mostly in the hands of women minorities who are working for a cleaning service agency. Thus, may explain for why the vacuum cleaner is only found in $O$ : The Oprah Magazine whose readers are not only the European white but also includes the black African-American readers.

The above discussion, nevertheless, shows that ever since the World War II era and up to now, many women think that owning modern household machines will help perform the dual responsibility of a mother or housewife and worker better. Walker (2000) gives the understanding that purchasing certain products and appliances promises women to be out from lower class drudgery. The following samples of texts found in advertisements show how advertisers try to influence women into thinking how helpful a household appliance is. For example, is the "More Small Electric Appliances that Work for You" (Good Housekeeping, November $1950)$ that is used to describe a steam iron.

Another is in the advertisement of a Spray shortening, which is a basic ingredient to making Fried Chicken, Beef burger Toasties, and summertime Sherbert Cake. In the advertisement, a woman is shown opening up a refrigerator door to get rid of the heat of the day with a text that says: "To the Woman who thinks it is too hot to cook! You will spend less time in your kitchen if you use these modern short-cuts-New methods [which is] only possible because Spry is homogenized" (Ladies' Home Journal, August 1953).

Although women are thankful to have these modern appliances most have not realized that having all of those facilities have just given emphasis on the fact that women are being undervalued by society. In other words, the kinds of house work women usually do are understood as non-important. By purchasing modern household machines, it could be said that women are empowered by the men who prefer to have women stay at home. Thanks to "Home Economics High School Text Book" of 1954, a woman is able to learn how to become an ideal housewife, because it has been an aspiration before the end of the 1950s for many girls to be married and have a decent family life (Lamb, 2011, p. 1). The kinds of activities an ideal housewife would do is to maintain the house, prepare meals, take care of the children, help them with their 
homework, doing the dishes and laundry while remaining elegant.

Why do women not mind with the idea of being a housewife? Nies offers the reflection upon the American society that believes "a successful college woman of the era was supposed to have an engagement ring on her finger by the end of her senior year" (2008, p. 49). Meanwhile, Mintz and Kellogg (1988) refer to a speech given by a college student, Adlai Stevenson, in 1955 who says that, a woman's role in life was to "influence us, man and boy, to restore valid, meaningful purpose to life in your home" and "to keep their husbands truly purposeful". This is also similar to the text of an advertisement that ran: "What's college? That's where girls who are above cooking and sewing go to meet a man so they can spend their lives cooking and sewing” (Mintz \& Kellogg, 1988).

Discussing about the suburban family in the 1960s, which was a female dominated and pro-child one with a father's absence, it is learnt that this suburban society was created at the cause of having no new housing built during the twenty years men had been busy going to war, that it forced many people to leave the cities and settle in the districts. According to Lamb (2011) the housings with large gardens that range from $\$ 6,000$ to $\$ 62,000$ in the suburbs appealed to all lowaverage to higher class people (p. 7). This appeal was far greater when in the cities many kinds of jobs are abundantly available and that the community in the suburbs was helpful in providing a share of some of the neighborhood's cars for people who had to work in the cities. The safety of the children was also the attraction of the suburbs because some mothers offer help in raising the children of other mothers who had to work in cities. It is for this reason that magazines make an effort of not only domesticating women to do housework but also in reminding women to raise their children well. Articles from the popular Dr. Benjamin Spock, who wrote a regular column for Ladies' Home Journal in the beginning of July 1954 (Walker, 2000, p. 174) were among those that women read at a regular basis to help make them become better mothers.

\section{MAGAZINE ADVERTISEMENTS' REPRESENTATION OF WOMEN AS MOTHERS}

It cannot be denied that women are mothers. That is the stereotype which grows in this world. However, motherhood relates to several meanings. According to Woodward (1999), motherhood is the identity position of the biological, social, and symbolic. Motherhood also means that women should behave, but cannot express their minds too freely (pp. 240-241). This means that women, in this case, mothers, are not allowed to stand out. Mothers are in the shadow of an understanding that they should abide to the rule of taking care of their children, husband, and their beautiful house. Woodward says, that mothers need not to be smart or express their mind because it is the "idealized standard which are culturally prescribed" (Woodward, 1999, p. 243). Hence, mothers cannot be separated from the media, especially magazines, where it is used as an identity for "a shared imaginary community" (Woodward, 1999, p. 269). Mothers are depicted to do the housework and take care of their body, too. In doing the housework, advertisements through magazines spread the product to make mothers easy to do the housework. They seem to help mothers, but they do not.

As discussed earlier in this research, advertisers make ways for mothers to buy the household products to ease their work but at the same time, make some kind of agreement that it is a nature for women to keep staying at home. The psychoanalyst, Luce Irigaray argues that "the patriarchal system of representations exclude the mother from culture" (as cited in Woodward, 1999, p. 244), so, in order to speak rather than be spoken, mothers have to be put into a "subject- 
position" but one that is "not as identical as a woman" (Woodward, 1999, p. 245).

The following are samples, whose theme travel through time and space, i.e. about how a mother is represented in magazines as provider of a family's healthy meal and child rearing, which among others must be concerned about children's health like shown in this Unguentine First-Aid spray advertisement from Ladies' Home Journal June 1961, p.24). Other advertisement samples are how a mother or grandmother would show little girls how to become a good cook, or a mother about to bathe her children to signify how a mother is concerned with hygine, and healthy meals for the family like shown in Ladies' Home Journal, February 2008, p.73. To avoid the fact that women should be at home, the magazine has created a side job for women. One of those is the Ladies' Home Journal magazine, which offers the women to search for subscribers. If women can persuade friends to subscribe to the magazine, the magazine will give them an amount of money. Another strategy is for these women to send in menu or articles about their home cooking, such as that done by with the features of the Betty Crocker menu. This means women do not need to go outside the house to earn money. It makes mothers happy, but most importantly it makes the magazine happy, too, as it gets more subscribers and also get more support from those who wants to keep the women at home.

\section{ENTRAPPING WOMEN WITH BEAUTY TIPS}

Ever since the 1950s up to now, magazine advertisements also influence the hegemony of women, through the trap of making women think that they will not be as attractive if not using the kinds of fashion and makeup magazine advertisements suggest. As seen in the advertisements, the Emily Tyler style fashion (Ladies' Home Journal, December 1960, p. 127) i.e. women wearing a long gown or skirt has used the strategy of luring women to buy their fashion product by making women feel they can be as important as a princess or first lady hosting a ballroom function that daughters are also encouraged to dress in a similar fashion as their mothers and use as minimal makeup they can for daily use. In the advertisement makeup tips, the text underneath the picture, it says:

I know boys who come right out and speak their disapproval of too much makeup," says Patsy Davis. The deb's favorite formula: lipstick and powder by day; for evening add a touch of mascara and eye shadow "if it does something for you" (Ladies' Home Journal, December 1960, p. 65)

The excerpt above shows that advertisers know exactly that women would read advertisements as a source of information for beauty tips. In suggesting the kinds of ideal beauty, advertisements have unfortunately manipulated women to be submissive also under the name of the patriarchy system.

In magazine advertisements, it may seem that women are given a way out to show their self-confidence and self-esteem by choosing for example, their own kinds of cosmetics through the range of cosmetic samples shown in magazine advertisements. However, consciously aware or not, women want to be made beautiful and adored by the men and other women. To a feminist, this condition actually signifies that women want to become an object that can please those in the patriarchy level of hegemony. For a capitalist, which in this case includes corporations and advertising agencies, knowing that women aspires for a clean, fresh and younger looking face, they make a system where women would depend on them to find some kind of identity by being different or better than others.

Advertisers know that women are not usually satisfied with their own condition and look to 
others for some kind of identity because it is in the difference that women find their identity. For this reason, advertisers make sure that their product stands out and attracts the women magazine reader to look more than once to their advertised product.

\section{CONCLUSION}

Advertisers know that women are their best consumers. The research discussed here sets out with the question on how the magazine advertisements can trap and influence women readers as consumer culture. The answer to this is, magazine advertisements managed to position women as the decision maker, thereby with many influential visual and verbal texts women are made to not only want but feel they need the product.

The second question is how the adverstisements can signal the dream of achieving a global self-identity. The answer to this is, advertisements play with a freedom imagery, so women can freely exercise their democracy of choosing the array of products they desire to have and consume continually as they elevate their self-identity and social status.

The last question on whether or not the women images used in the advertisements have a gender ideology intent, is answered in the idea that cultural patriachy hegemony make ways for women to fulfill Friedan's categorization of either the True Housewife, the Career Woman, or the Balanced Homemaker type.

As an American Studies research that base heavily on women magazine advertisements as data for Popular Culture, the research, which is grounded in nature manages to sum up the interpretation and analysis of magazine advertisements as emitting the following theories: (1) American hegemony is possible by way of the transnationality of popular culture, (2) women magazine advertisements is the best media to reach out to women who are the number one target of consumer culture, (3) cultural hybridity exists only when there is a negotiation of cultural diversity, (4) cultural homogeneity results from a borderless world of popular culture, (5) the construction of a pseudofreedom and egalitarian position for career women is constraint by nature's gender ideology and patriarchy hegemony, (6) the representations of women in magazine advertisements is the gender ideology of women as the only true housewife, balanced homemaker, and best provider of families' health; and (7) the highest satisfaction in a woman is when she fulfils the myth of the beautiful chattel men are continually competing for.

\section{REFERENCES}

Beeson, M. (2004). The Rise of the 'Neocons' and the Evolution of American Foreign Policy. Australia: Murdoch University.

Beng-Huat, C. (2000). Consumption in Asia: Lifestyle and Identities. London \&New York: Routledge.

Casey, S. (2007, February). O: The Oprah Magazine. USA: Hearst Co.

Casey, S. (2007, May). O: The Oprah Magazine. USA: Hearst Co.Casey, S. (2007, August). O: The Oprah Magazine. USA: Hearst Co.

Casey, S. (2007, November). O: The Oprah Magazine. USA: Hearst Co.

Crockatt, R. (2007). After 9/11: Cultural Dimension of American Global Power. New York: Toutledge.

Fatimah, P. S. (2007, Mei 24-30 Mei) Femina. Jakarta: PT Grafika Multi Warna.

Fatimah, P. S. (2008, Mei 29- Juni 4) Femina. Jakarta: PT Grafika Multi Warna. 
Ferguson, M. (1983). Forever Feminine: Women's Magazines and the Cult of Feminity. London: Heinemann.

Fishkin, S. F. (2004, March). "Crossroads of Cultures: The Transnational Turn in American Studies: Presidential Address to the American Studies Association, November 12, 2004. In American Quarterly, 57 (1), 17-57.

Fuller, W.D. (December, 1960). Ladies' Home Journal. USA: The Curtis Publishing Co.

Gough-Yates, A. (2003). Understanding Women's Magazines: Publishing, Markets and Readerships. London: Routledge.

Hall, S. (2002). Representation: Cultural Representations and Signifying Practices. London: Sage Publications Ltd.

Kammen, M. (1999). American Culture, American Tastes: Social Change and the Twentieth Century. New York: Knopf.

Lagani, D. K., (2008, November). Cosmopolitan. USA: Hearst Magazine Division.

Lagani, D. K. (2009, September 3). "Fun Fearless Female - Conversations from Penn State. Franklin, B. (Interviewer). Retrieved August 15, 2014 from www.youtube.com/watch? $\mathrm{v}=$ UDKO66jLDII.

Lamb, V. M. (2011). The 1950's and 1960's and the American Woman: the transition from the "housewife" to the feminist. Retrieved November 14, 2014, from History: dumas.ccsd.cnrs.fr/dumas-0068821

Lindquist, J. D., \& Sirgy, M. J. (2006). Shopper, Buyer, and Consumer Behavior. U.S.A.: Atomic Dog Publishing.

Marchand, R. (1986). Advertising the American Dream: Making Way for Modernity 1920-1940. Berkeley: University of California Press.
McLuhan, M. (2002). Understanding Media: The Extensions of Man. USA: Gingko Press.

Mintz, S., \& Kellogg, S. (1988). Domestic Revolutions: A Social History of American Family Life. New York: The Free Press.

Nies, J. (2008). The Girl I left Behind: A Narrative History of the Sixties. USA: Harper Collins.

Ritzer, G. (1998). The McDonaldization Thesis. London, Thousand Oaks, New Delhi: Sage Publications.

Rowe, J. C. (2002). "Postnationalism, Globalism, and the New American Studies". In D. E. Pease \& R. Wiegman (Eds.), The Futures of American Studies (pp. 167-182). USA: Duke University Press.

Soedarjo, D. M. (2007, Februari). Cosmopolitan. Jakarta: PT Indonesia Printer.

Tomagola, T. A. (1998). Citra Wanita dalam Iklan dalam Majalah Wanita Indonesia: Suatu Tinjauan Sosiologi Media. In I. S. Ibrajim, \& H. Suranto (Eds.), Wanita dan Media: Konstruksi Ideology Gender dalam Ruang Publik Orde Baru (pp. 330-347). Bandung: PT Remaja Rosdakarya.

Tomlinson, J. (1991). Cultural Imperialism: a Critical Introduction. London: Continuum. Tuttle, W. M. (1993). "Daddy's Gone to war": The Second World War in the Lives of America's Children. New York: Oxford University Press.

Walker, N. A. (2000). Shaping Our Mother's World: American Women's Magazines. USA: University Press of Mississippi.

Walker, N. A. (1998). Women's Magazines 1940-1960: Gender Roles and the Popular Press. Boston New York: Bedford Press/ St Martins.

Woodward, K. (1999). Identity and Difference. London: SAGE Publications Ltd. 